Egyptian Journal for Aquaculture

ISSN: 2090-7877

www.braesd.org

Reham et al., 2018; 8(3):55-69

\title{
The inhibitory effect of some natural volatile oils on Cyanobacteria (Anabaena wisconsinense) and some Pathogenic Bacteria
}

Reham, A. E. Abd El Hay ${ }^{1}$, Eman, A. A. Abd El Hamid ${ }^{1}$, Ahmed, M.M. ElAshram $^{2}$

1- Limnology Dept., Central Lab. for Aquaculture Research, Agricultural Research Center.

2- Fish Health and Diseases Dept., Faculty of Fish Resources, Suez University, Egypt.

Received: July 17, 2018; Accepted: August 26, 2018 published: Sept. 2018 Vol.8 (3):55-69

\section{ABSTRACTS}

The main objective of this study was to test the inhibitory effect of clove oil (Syzygium aromaticum), peppermint oil (Mentha longifolia), basil oil (Ocimum basilicum) and castor oil (Ricinus communis) on the growth of cyanobacteria (Anabaena wisconsinense) as well as four pathogenic bacteria (Escherichia coli, Vibrio sp. Pseudemonas sp. and Aeromonas sp.).

The algicidal activity of investigated volatile oils was tested at 3 concentrations of the crude oils $(50,100,150 \mathrm{ppm})$ on the growth of Anabaena wisconsinense, and at 3 volumes (10, 20, $30 \mu \mathrm{l})$ on the growth rates of the tested species of pathogenic bacteria. Results showed that the investigated volatile oils have a strong antagonistic effect on Anabaena wisconsinense. Clove and peppermint oils were the highest inhibitory action against A. wisconsinense. Growth rates of all tested bacteria Also were inhibited with clove and peppermint oils while basil and castor oils had no effect against Pseudemonas sp. and Aeromonas sp. at any volumes.

Anabaena wisconsinense and pathogenic bacteria were more sensitive to the allelopathic and antibacterial effect of clove and peppermint oils.

Keywords: Biocontrol, Clove, Peppermint, Basil, Castor Cyanobacteria, Pathogenic Bacteria

\section{INTRODUCTION}

Toxic cyanobacteria are found worldwide coastal water environments. At least 46 species have been known to cause toxic effects in vertebrates (Sivonen and Jones, 1999). The most common toxic cyanobacteria in freshwater are Microcystis spp., Cylindrospermopsis raciborskii, 
Planktothrix (syn. Oscillatoria) rubescens, Synechococcus spp., Planktothrix (syn. Oscillatoria) agardhii, Gloeotrichia spp., Anabaena spp., Lyngbya spp., Aphanizomenon spp., Schizothrix spp. and Synechocystis spp. (Chorus and Bartram, 1999). Anabaena is one of four cyanobacteria genera that produce neurotoxins, which are harmful to local wildlife. Many of the bloom forming cyanobacteria produce toxins responsible for mass mortality of aquatic and exposed vertebrate populations (Paerl et al., 2001). Many mechanical and physiochemical methods have been devised in attempts to manage cyanobacterial blooms with limited success. The most direct control method involves the use of chemical treatments such as algicides, including copper, Reglone A (diquat, 1, 1- ethylene-2, 2-dipyridilium dibromide), potassium permanganate, chlorine and Simazine (2-chloro-4,6- bis (ethylamino)-striazine (Lam et al., 1995). Copper sulphate or organo-copper compounds have been used successfully to control harmful algal blooms in raw water supplies intended for human consumption (Lam et al., 1995). These chemicals induced cyanobacterial cell lysis, followed by the release of toxins into surrounding water. New and alternative approach to control the algal blooms involves the use of plant extracts exactly the essential oils. Plants and other natural sources can provide an extended range of complex and structurally diverse compounds. Plant extracts and essential oils possess antifungal, antibacterial, and antiviral properties and have been screened on a global scale as potential sources of novel antimicrobial compounds, agents promoting food preservation, and alternatives to treat infectious diseases (Safaei-Ghomi and Ahd, 2010; Astani et al., 2010). Essential oils have been reported to possess significant antiseptic, antibacterial, antiviral, antioxidant, anti-parasitic, antifungal, and insecticidal activities (Kaloustian et al., 2008 and Burt, 2004). Therefore, essential oils can serve as a powerful tool to reduce the bacterial resistance (Stefanakis et al., 2013) in fish pathogens such as E. coli, Pseudomonas sp., Vibrio sp. and Aeromonas hydrophila, which cause serious diseases in aquaculture with high economic loss. The use of antibiotics in aquaculture has led to the development of the resistant strains and may be reducing the fish growth or immune response beside involving environmental hazards (Cañada et al., 2009; Chakraborty and Hancz, 2011). Antibiotics also can accumulate in soil or sediment and become harmfull for environment. Recently, many essential oils and plant extracts have been shown to be effective against fish pathogens (Direkbusarakom, 2004; Bansemir et al., 2005; Hindi and Chabuck, 2013). 
Various chemotherapeutics have been used to treat bacterial infections in cultured fish for the last decades. However, the incidence of drugresistant bacteria has became a major problem in fish culture (Aoki, 1992). The medicinal plants are currently used in commercial aquaculture as growth promoting substances, nutrients and antimicrobial agents for preventing and controlling of fish diseases. It developed as an environmentally sound supplement alternatively to the use of chemicals and for producing organic fish (Galina et al., 2009).

The aim of this study is investigate the influence of some concentrations of clove (Syzygium aromaticum), peppermint (Mentha longifolia), Basil (Ocimum basilicum) and Castor (Ricinus communis) oils on the growth of cyanobacteria (Anabaena wisconsinense) as well as four different pathogens (E. coli, Vibrio sp. Pseudemonas sp. and Aeromonas sp.).

\section{Materials and Methods}

\section{Cultivation of Anabaena wisconsinense}

Strains of the Cyanobacteria Anabaena wisconsinense was isolated from Abbassa fish ponds (Reham, 2012) and cultivated in the phytoplankton laboratory belongs to limnology department, Center laboratory for aquaculture research (CLAR) according to Venkataraman (1969). Alga grow as single cell in BG11 liquid media which adjusted to $\mathrm{pH} 8$ with $\mathrm{NaOH}$ and $\mathrm{HCl}$ (Rippka et al., 1979). The Cyanobacteria were incubated at $26 \pm 1{ }^{\circ} \mathrm{C}$ under an illumination intensity of 2500 lux, with a $12 / 12 \mathrm{~h}$ light / dark interval. The microalga was cultivated to the exponential growth phase for use. The density was monitored every two days.

\section{Preparation of the pure alga for inoculation}

Cyanobacteria Anabaena wisconsinense culture in $50 \mathrm{ml}$ was prepared as primary inoculum, and then $500 \mathrm{ml}$ of cultured media was prepared and inoculated with it, and incubated at $26 \pm 1{ }^{\circ} \mathrm{C}$ in the presence of light for 14 days.

\section{The investigated oils:}

The investigated oils Clove (Syzygium aromaticum), Peppermint (Mentha longifolia), Basil (Ocimum basilicum) and Castor (Ricinus communis) used in the present study were obtained from the local market of Zagazig city.

Activity evaluation of the investigated oils against Cyanobacteria (Anabaena wisconsinense)

The algicidal activity of the four investigated volatile oils were tested at 3 concentrations of the crude oils $(50,100,150 \mathrm{ppm})$ and monitored 
throughout 12 days against the A. wisconsinense isolate According to (Kim et al., 2002). The investigated oils were dissolved in equal volumes of $95 \%$ ethanol $(\mathrm{V}: \mathrm{V}, 50 \%)$. The test results indicated that the concentrations of ethanol added had no effect on the growth of the tested alga. The tested oils were added to a flask containing $20 \mathrm{ml}$ of alga and $180 \mathrm{ml}$ of culture media (BG11). During the experiment, the culture condition (temperature, and light) were adjusted as mentioned before. The density of alga was monitored every 2 days by the estimation of chlorophyll-a content (indirect method of Cyanobacterial biomass determination), where the pigment can be completely extracted in aceton.

\section{The estimation of chlorophyll- a:}

The cyanobacterial culture was taken and centrifuged at $5000 \mathrm{rpm}$ for $10 \mathrm{~min}$. the pellet was washed twice in distilled water, thus the pellet was re-suspended in $4 \mathrm{ml}$ of $80 \%$ acetone and vortexes thoroughly. Tubes were incubated in a water bath at $60^{\circ} \mathrm{C}$ for $1 \mathrm{~h}$ in dark with occasional shaking. The suspension was centrifuged at $5000 \mathrm{rpm}$ for $10 \mathrm{~min}$ and the supernatant was stored. Absorbance of the supernatant was read at $663 \mathrm{~nm}$ in U.V. spectrophotometer against $80 \%$ acetone as blank.

The amount of chlorophyll a in the sample was calculated according to Kim et al. (2002) using the following formula:-

\section{A663 $\times 12.63 \times$ volume of acetone}

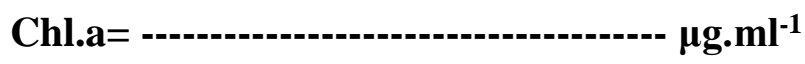

\section{Volume of sample}

A663: absorbance at $663 \mathrm{~nm}$.

12.63: correction factor and the amount were expressed as $\mu \mathrm{gml}^{-1}$.

\section{Bacterial isolation}

Escherichia coli, Aeromonas sp., Pseudomonas sp. and Vibrio sp. were isolated from polluted water source. For enumeration of coli form group and E. coli, MacConkey agar was used while, for vibrio cholera selective media, Thiosulphate-Citrate-Bile-Sucrose agar (T.C.B.S) was used. Also selective media pseudomonas was used for isolation Pseudomonas sp. the isolated bacteria were identified according to standards bacteriological methods described by APHA (1989).

\section{Bacterial culture preparation}

Nutrient broth (NB) was prepared and was inoculated with the tested organisms. A loop full of microorganism was taken and inoculated in the $\mathrm{NB}$ and was incubated at $37^{\circ} \mathrm{C}$ for $24 \mathrm{hrs}$ to obtain a viscous growth. Cotton 
swabs were dipped in the culture broth and were swabbed on the solidified media surface previously prepared in petri dishes.

Antibacterial activity (In vitro) of investigated oils by Paper disk assay according to (Bauer et al., 1966):

Antibacterial activity of tested oils in vitro was carried out using disc diffusion method. The sterilized nutrient agar (NA) medium poured in sterilized Petri dishes. After solidification the plates were inoculated with $0.1 \mathrm{ml}$ of fresh bacterial suspension ( $24 \mathrm{~h}$ live). Sterilized paper discs were impregnated with $(20,40$ and $60 \mu \mathrm{l})$ diluted tested oils, where tested oils were dissolved in equal volumes $(\mathrm{V}: \mathrm{V}, 50 \%)$ of $95 \%$ ethanol and air dried. Another sterilized paper discs were impregnated with ethanol at (10, 20 and $30 \mu \mathrm{l})$ and used as control. Paper discs were placed over the agar surface. The plates incubated at $37^{\circ} \mathrm{C}$ for $24 \mathrm{hrs}$ and examined for inhibition. The diameter of the inhibition zones were measured in millimeters.

Allelopathic activity on growth inhibition: was estimated by percentage of inhibition (PI), which is defined as follow -:

Inhibition percentage (IP \%) $=[($ diameter of inhibition zone in treated bacteria - diameter of inhibition zone in control)/diameter of normal growth $\times 100]$.

\section{Statistical analysis}

Statistical analysis was applied according to Steel and Torrie (1980), data were analyzed using the GLM procedure with two way analysis of variance (SAS, 2002), Differences between means were tested for significance according to Duncan's multiple rang test (Duncan, 1955).

\section{Results and Discussion}

1- The evaluation of the investigated oils against Cyanobacteria (Anabaena wisconsinense) :

Our results in (Table 1) recorded that, in clove oil the highest anti-algal impact expressed as $0 \mu \mathrm{g} / \mathrm{ml}$ as chlorophyll-a concentration at 100 and $150 \mathrm{ppm}$ from the $8^{\text {th }}$ day till the end of the experiment and the same result was obtained in peppermint at the concentration of $100 \mathrm{ppm}$ at the $12^{\text {th }}$ day and at concentration $150 \mathrm{ppm}$ from the $4^{\text {th }}$ day till the end of the experimental period. Compared by the control group (algae free from any oils), that represented continuous increased in concentration of chlorophyll a along with time as shown in Table(1). 
Table (1). Effect of different concentrations of different investigated oils on A. wisconsinense density expressed as chlorophyll a concentrations $\left(\mu \mathrm{g} . \mathrm{ml}^{-1}\right)$

\begin{tabular}{|c|c|c|c|c|c|c|c|}
\hline \multirow[b]{2}{*}{ Treatments } & \multirow[b]{2}{*}{$\begin{array}{l}\text { Concentrations } \\
\text { ppm. }\end{array}$} & \multicolumn{6}{|c|}{ Concentration of chlorophyll a $(\mu \mathrm{g} / \mathrm{ml})$} \\
\hline & & $\begin{array}{l}2^{\text {nd }} \\
\text { day }\end{array}$ & $4^{\text {th }}$ day & $6^{\text {th }}$ day & $\begin{array}{c}8^{\text {th }} \\
\text { day }\end{array}$ & $\begin{array}{l}10^{\text {th }} \\
\text { day }\end{array}$ & $\begin{array}{l}12^{\text {th }} \\
\text { day }\end{array}$ \\
\hline Control & 0 & $\begin{array}{r}0.05^{\mathrm{a}} \\
\pm 0.01\end{array}$ & $\begin{array}{c}0.11^{\mathrm{d}} \\
\pm 0.02\end{array}$ & $\begin{array}{c}0.5^{\mathrm{b}} \\
\pm 0.3\end{array}$ & $\begin{array}{c}0.9^{\mathrm{a}} \\
\pm \\
0.02\end{array}$ & $\begin{array}{c}3.4^{\mathrm{a}} \\
\pm 0.03\end{array}$ & $\begin{array}{r}6.6^{\mathrm{a}} \\
\pm 0.01\end{array}$ \\
\hline \multirow{3}{*}{ Clove Oil } & 50 & $\begin{array}{c}0.08^{\mathrm{b}} \\
\pm 0.02\end{array}$ & $\begin{array}{c}0.03^{\mathrm{e}} \\
\pm 0.03\end{array}$ & $\begin{array}{l}0.03^{\mathrm{e}} \\
\pm 0.2\end{array}$ & $\begin{array}{c}0.03^{\mathrm{e}} \\
\pm \\
0.06\end{array}$ & $\begin{array}{l}0.02^{\mathrm{e}} \\
\pm 0.1\end{array}$ & $\begin{array}{l}0.01^{\mathrm{d}} \\
\pm 0.5\end{array}$ \\
\hline & 100 & $\begin{array}{c}0.01^{\mathrm{f}} \\
\pm \\
0.01 \\
\end{array}$ & $\begin{array}{c}0.005^{\mathrm{g}} \\
\pm 0.1\end{array}$ & $\begin{array}{l}0.003^{\mathrm{f}} \\
\pm 0.2\end{array}$ & $\begin{array}{c}0^{\mathrm{g}} \\
\pm \\
0.01 \\
\end{array}$ & $\begin{array}{c}0^{g} \\
\pm 0.5\end{array}$ & $\begin{array}{c}0^{\mathrm{f}} \\
\pm 0.03\end{array}$ \\
\hline & 150 & $\begin{array}{l}0.02^{\mathrm{f}} \\
\pm 0.1 \\
\end{array}$ & $\begin{array}{c}0.005^{\mathrm{g}} \\
\pm 0.2 \\
\end{array}$ & $\begin{array}{c}0.003^{\mathrm{f}} \\
\pm 0.1 \\
\end{array}$ & $\begin{array}{c}0^{\mathrm{g}} \\
\pm 0.1 \\
\end{array}$ & $\begin{array}{c}0^{\mathrm{g}} \\
\pm 0.1 \\
\end{array}$ & $\begin{aligned} & 0^{\mathrm{f}} \\
& \pm 0.01 \\
&\end{aligned}$ \\
\hline \multirow{3}{*}{$\begin{array}{l}\text { Peppermint } \\
\text { Oil }\end{array}$} & 50 & $\begin{array}{c}0.05^{\mathrm{d}} \\
\pm 0.03\end{array}$ & $\begin{array}{l}0.1^{\mathrm{d}} \\
\pm 0.5\end{array}$ & $\begin{array}{c}0.07^{\mathrm{d}} \\
\pm 0.04\end{array}$ & $\begin{array}{c}0.03^{\mathrm{e}} \\
\pm \\
0.02 \\
\end{array}$ & $\begin{array}{l}0.02^{\mathrm{e}} \\
\pm 0.2\end{array}$ & $\begin{array}{r}0.005^{\mathrm{e}} \\
\pm 0.1\end{array}$ \\
\hline & 100 & $\begin{array}{c}0.04^{\mathrm{e}} \\
\pm 0.03\end{array}$ & $\begin{array}{l}0.02^{\mathrm{f}} \\
\pm 0.2\end{array}$ & $\begin{array}{c}0.02^{\mathrm{e}} \\
\pm 0.05\end{array}$ & $\begin{array}{c}0.01^{\mathrm{f}} \\
\pm \\
0.04\end{array}$ & $\begin{array}{c}0.005^{\mathrm{f}} \\
\pm 0.2\end{array}$ & $\begin{array}{c}0^{\mathrm{f}} \\
\pm 0.02\end{array}$ \\
\hline & 150 & $\begin{array}{r}0.02^{\mathrm{f}} \\
\pm 0.01\end{array}$ & $\begin{array}{c}0^{\mathrm{h}} \\
\pm 0.1\end{array}$ & $\begin{array}{c}0^{\mathrm{g}} \\
\pm 0.02\end{array}$ & $\begin{array}{c}0^{\mathrm{g}} \\
\pm \\
0.03\end{array}$ & $\begin{array}{c}0^{\mathrm{g}} \\
\pm 0.1\end{array}$ & $\begin{array}{c}0^{\mathrm{f}} \\
\pm 0.03\end{array}$ \\
\hline \multirow{3}{*}{ Basil Oil } & 50 & $\begin{array}{c}0.09^{\mathrm{b}} \\
\pm 0.4\end{array}$ & $\begin{array}{c}0.6^{\mathrm{a}} \\
\pm 0.4\end{array}$ & $\begin{array}{c}0.7^{\mathrm{a}} \\
\pm 0.1\end{array}$ & $\begin{array}{c}0.7^{\mathrm{c}} \\
\pm 0.1 \\
\end{array}$ & $\begin{array}{c}0.8^{\mathrm{d}} \\
\pm 0.03\end{array}$ & $\begin{array}{r}2.1^{\mathrm{b}} \\
\pm 0.2 \\
\end{array}$ \\
\hline & 100 & $\begin{array}{l}0.07^{\mathrm{c}} \\
\pm 0.2 \\
\end{array}$ & $\begin{array}{r}0.6^{\mathrm{a}} \\
\pm 0.3 \\
\end{array}$ & $\begin{array}{c}0.7^{\mathrm{a}} \\
\pm 0.07 \\
\end{array}$ & $\begin{array}{c}0.7^{\mathrm{c}} \\
\pm 0.1 \\
\end{array}$ & $\begin{array}{c}0.8^{\mathrm{d}} \\
\pm 0.1 \\
\end{array}$ & $\begin{array}{c}2.2^{\mathrm{b}} \\
\pm 0.5\end{array}$ \\
\hline & 150 & $\begin{array}{r}0.14^{\mathrm{a}} \\
\pm 0.06\end{array}$ & $\begin{array}{c}0.21^{\mathrm{c}} \\
\pm 0.02\end{array}$ & $\begin{array}{c}0.026^{\mathrm{e}} \\
\pm 0.1\end{array}$ & $\begin{array}{c}0.3^{\mathrm{d}} \\
\pm 0.3 \\
\end{array}$ & $\begin{array}{c}0.91^{\mathrm{c}} \\
\pm 0.03\end{array}$ & $\begin{array}{c}1.4^{\mathrm{c}} \\
\pm 0.4\end{array}$ \\
\hline \multirow{3}{*}{ Castor Oil } & 50 & $\begin{array}{l}0.05^{\mathrm{d}} \\
\pm 0.2 \\
\end{array}$ & $\begin{array}{c}0.2^{\mathrm{c}} \\
\pm 0.03 \\
\end{array}$ & $\begin{array}{c}0.4^{\mathrm{c}} \\
\pm 0.04 \\
\end{array}$ & $\begin{array}{c}0.6^{\mathrm{c}} \\
\pm 0.1 \\
\end{array}$ & $\begin{array}{c}0.9^{c} \\
\pm 0.01 \\
\end{array}$ & $\begin{array}{c}2.6^{\mathrm{b}} \\
\pm 0.1 \\
\end{array}$ \\
\hline & 100 & $\begin{array}{c}0.08^{\mathrm{b}} \\
\pm 0.03\end{array}$ & $\begin{array}{c}0.4^{\mathrm{b}} \\
\pm 0.11\end{array}$ & $\begin{array}{l}0.55^{\mathrm{b}} \\
\pm 0.1\end{array}$ & $\begin{array}{c}0.7^{\mathrm{c}} \\
\pm \\
0.02 \\
\end{array}$ & $\begin{array}{c}1.3^{\mathrm{b}} \\
\pm 0.01\end{array}$ & $\begin{array}{l}2.09^{\mathrm{b}} \\
\pm 0.3\end{array}$ \\
\hline & 150 & $\begin{array}{c}0.1^{\mathrm{a}} \\
\pm 0.9\end{array}$ & $\begin{array}{c}0.6^{\mathrm{a}} \\
\pm 0.01\end{array}$ & $\begin{array}{c}0.7^{\mathrm{a}} \\
\pm 0.3 \\
\end{array}$ & $\begin{array}{c}0.8^{\mathrm{b}} \\
\pm 0.2 \\
\end{array}$ & $\begin{array}{c}1.2^{\mathrm{b}} \\
\pm 0.01\end{array}$ & $\begin{array}{l}2.2^{\mathrm{b}} \\
\pm 0.1\end{array}$ \\
\hline
\end{tabular}

Means \pm standard error. Values in the same column having the same superscript letters are not significantly different $(\mathrm{P}<0.05)$.

There were also inhibition effect in alga growth with both basil and castor oils at the three tested concentrations but less than clove and peppermint oils. The clove and peppermint oils were the highest inhibitory action with $A$. wisconsinense, where the inhibition effect was started in 
basil oil from $8^{\text {th }}$ comparing with control. There was significant difference in chlorophyll-a concentrations $(0.9 \mu \mathrm{g} / \mathrm{ml})$ in control at 8th day and chlorophyll-a concentrations $(0.7,0.7$ and $0.3 \mu \mathrm{g} / \mathrm{ml})$ in basil oil at $(50,100$ and $150 \mathrm{ppm}$ ) respectively. In castor oil the algicidal activity started from $6^{\text {th }}$ day where chlo-a concentration was $(0.4 \mu \mathrm{g} / \mathrm{ml})$ at $50 \mathrm{ppm}$ but increased at $150 \mathrm{ppm}$ to reach 0.7 while was $0.5 \mu \mathrm{g} / \mathrm{ml}$ in control.

The inhibition in Anabaena growth may be due to the allelochemical effect of the investigated oils. our results agrees with Wang et al., 2015 who reported an antagonestic activity of essential oils extracted from six submerged plants Potamogeton cristatus, P. maackianus, P. lucens, Vallisneria spiulosal, Ceratophyllum demersum and Hydrilla verticellata, showed high potency on M. aeruginosa. Kobaisy et al. (2001) found slightly inhibitory effect of Hibiscus cannabinus leaves oil extract against Oscillatoria perornata and no effect against one type of green algae. There was no algicidal activity observed for the oil major components when tested separately under the same conditions as the essential oil. Rosmarinus officinalis essential oil has high antagonistic effects on the growth rate of both Microcystis aeruginosa and Chroococcus measuring expressed as chlorophyll-a of each alga. Generally, growth rates of both algae severely decreased as the period and the concentrations of the essential oil increased comparing with which exponentially increased along with time. $M$. aeruginosa was more sensitive to the allelopathic effect of the oil (Najem et al., 2016). The possible explanation for the better activity of the essential oil could be due to easier absorption of the essential oil and lipophilic extracts into the cell body of the algae (Yi et al., 2011). (Barani et al., 2014) found that essential oils of three plants Satureja khuzistanica, Satureja rechingeri, and Zataria multiflora, strongly inhibited the growth of the dinoflagellate Cochlodinium polykrikoides that cause red tide.

\section{2- Evaluation the activity of the investigated oils against some pathogenic bacteria:}

In Table 2, Percentage of inhibition (IP\%) pathogenic bacterial growth by investigated oils, were recorded according to the size of inhibition zone formed on the agar plates by disc diffusion method. The maximum percentages of inhibition $(17,16.67$ and $16.42 \%)$ were recorded at concentrations (60,20 and $20 \mu 1$.) against Pseudomonas sp. and E coli with clove, basil and castor crude oils respectively. Clove and Peppermint crude oils were recorded positive inhibitions with all tested bacteria but basil and castor oils had no effect on Pseudomonas sp. and Aeromonas sp. comparing by control so were recorded negative percentages of inhibition bacterial growth with all concentrations. From fig 2 examined clove oil 
showed comparatively good effect on all pathogenic strains of bacteria comparing with control (ethanol only). The maximum inhibition were recorded at diluted concentration 60 and $40 \mu \mathrm{l}$. respectively against Pseudomonas sp. and the lowest were at conc. 60 and10 $\mu$ l. respectively, against Vibrio sp.. Pandey and Singh (2011) mentioned that clove oil revealed inhibition zones against food borne pathogens (Staphylococcus aureus, Pseudomonas aeruginosa, Escherichia coli),using agar diffusion susceptibility test. Compare to ethanolic extract, methanolic extract was showing best result against gram positive culture Staphylococcus aureus (MTCC 2940) and two gram negative cultures Pseudomonas aeruginosa (MTCC 2453) and E. coli (MTCC 739). Meeker and Linke (1988) and Walsh and Pease (2002) proved that clove oil is rich in eugenol, isoeugenol and methyleugenol which have antifungal, antibacterial, antiviral, anti-inflammatory, antioxidant and anesthetic properties.

Table (2). Inhibition percentage (IP\%) of pathogenic bacterial growth by investigated oils:

\begin{tabular}{|l|c|c|c|c|c|}
\hline Treatments & $\begin{array}{c}\text { Oils crude } \\
\text { concentration } \\
(\mu \mathrm{l})\end{array}$ & \multicolumn{5}{|c|}{$\begin{array}{c}\text { Percentage of inhibition (PI\%) Pathogenic } \\
\text { bacterial growth }\end{array}$} \\
\hline & & E.coli & $\begin{array}{l}\text { Vibrio } \\
\text { sp. }\end{array}$ & $\begin{array}{l}\text { Pseudomonas } \\
\text { sp. }\end{array}$ & $\begin{array}{l}\text { Aeromonas } \\
\text { sp. }\end{array}$ \\
\hline \multirow{3}{*}{ Clove Oil } & 20 & 10.25 & 1.67 & 8.58 & 9.17 \\
\cline { 2 - 6 } & 40 & 12.25 & 6.42 & 15.00 & 5.83 \\
\cline { 2 - 6 } & 60 & 5.25 & 2.25 & 17.83 & 4.75 \\
\hline \multirow{3}{*}{$\begin{array}{l}\text { Peppermint } \\
\text { Bil }\end{array}$} & 20 & 5.83 & -1.08 & 2.17 & 9.42 \\
\cline { 2 - 6 } & 40 & 7.75 & 2.75 & 13.83 & 4.75 \\
\hline \multirow{3}{*}{ Casil Oil } & 60 & 4.67 & 4.42 & 7.25 & 8.08 \\
\cline { 2 - 6 } & 20 & 16.67 & 13.33 & -13.92 & -16.67 \\
\cline { 2 - 6 } & 40 & 12.75 & 7.50 & -12.25 & -14.42 \\
\cline { 2 - 6 } & 60 & 6.92 & 10.83 & -12.75 & -14.42 \\
\cline { 2 - 6 } & 20 & 16.42 & 8.08 & -13.92 & -16.67 \\
\cline { 2 - 6 } & 40 & 14.25 & 7.75 & -12.25 & -14.42 \\
\hline
\end{tabular}

In Fig. 2, Peppermint oil effectiveness was observed against all examined bacterial pathogens. except Vibrio sp. where there was no significant different in inhibition zone at conc. $40 \mu \mathrm{l}$ compared with that of control. The highest antibacterial effect were obtained against Pseudomonas sp. and Aeromonas sp. at concentrations (40 and $20 \mu 1$.) respectively comparing with control. That agree with (Nikoli'c et al., 2014) 
who found potential antimicrobial activity of essential oils extracted from five plants namely, Mentha piperita (Peppermint),

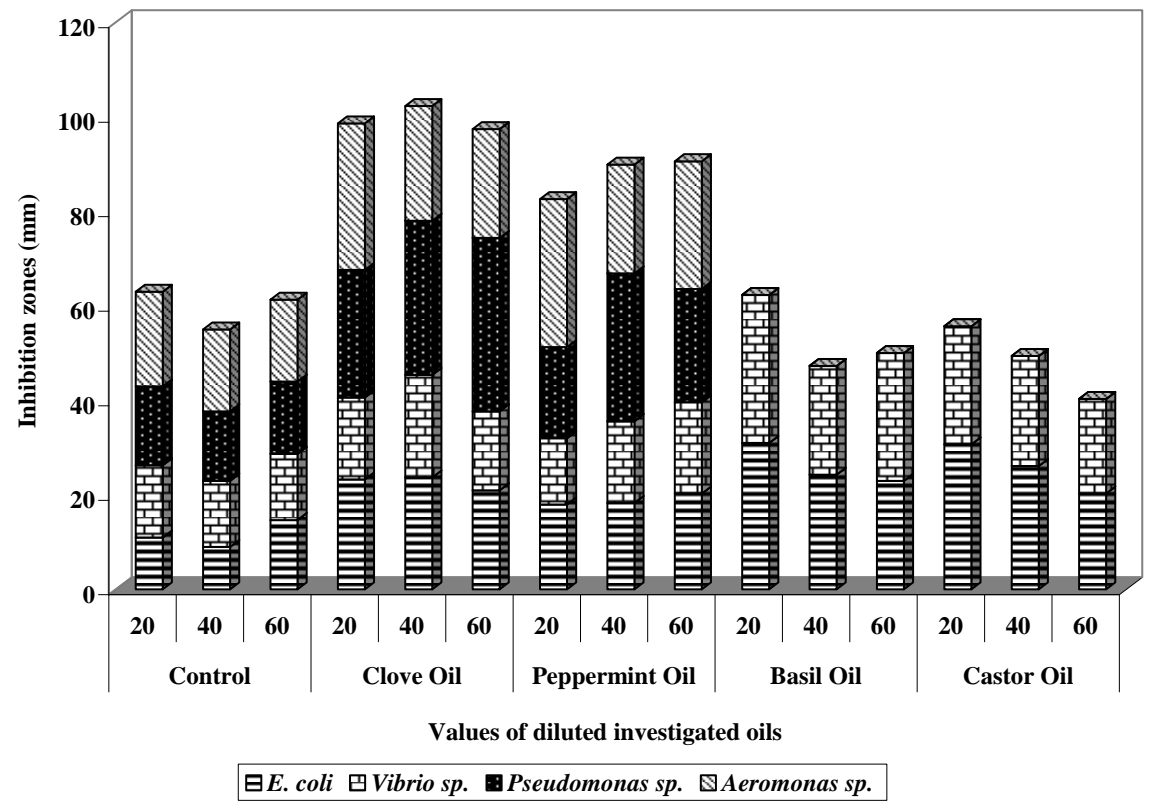

Figure (1). The effect of (Clove, Peppermint, Basil and Castor oils) on the growth of some pathogenic bacteria (inhibition zone measured as $\mathrm{mm}$ ):

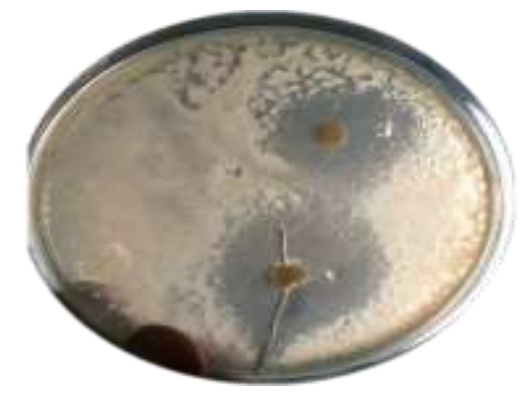

Photo (1). The effect of clove oil on Pseudomonas sp. growth at $60 \mu \mathrm{l}$ (measured as diameter of inhibition zone $(\mathrm{mm}))$.

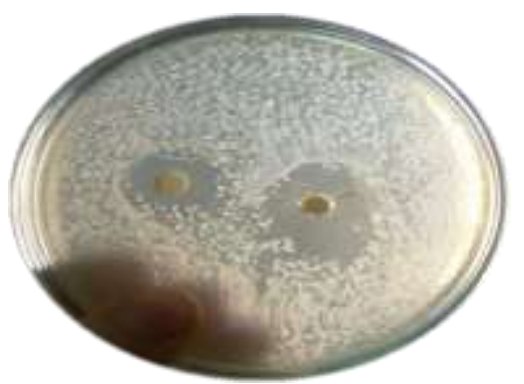

Photo (2). The effect of Peppermint oil on Aeromonas sp. at $60 \mu \mathrm{l}$ (measured as diameter of inhibition zone $(\mathrm{mm}))$. 


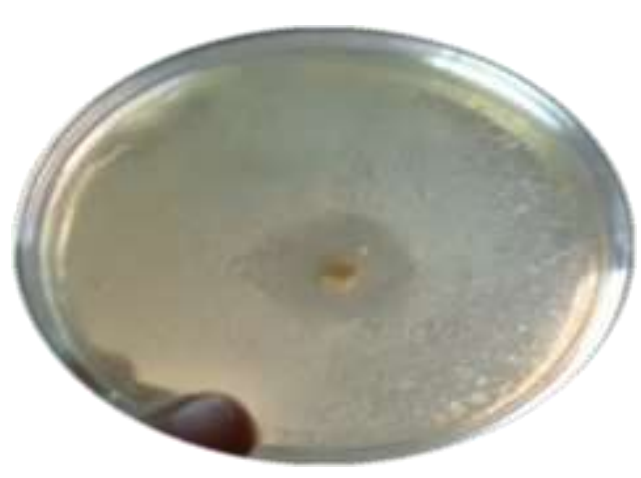

Photo (3). The effect of clove oil on Aeromonas sp. growth at $40 \mu \mathrm{l}$ (measured as diameter of inhibition zone $(\mathrm{mm}))$.

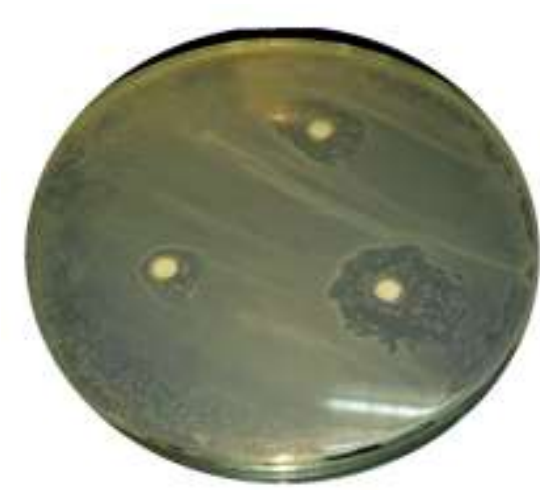

Photo (4). The effect of clove oil on E coli growth at $40 \mu 1$ (measured as diameter of inhibition zone $(\mathrm{mm})$ ).

Lavandula angustifolia, Mentha pulegium (Peppermint), Salvia lavandulifolia and Satureja montana against Pseudomonas aeruginosa, Streptococcus pyogenes, Streptococcus mutans, Streptococcus sanguis, Streptococcus salivarius, Enterecoccus feacalis and Lactobacillus acidophilus pathogenic bacteria. From Table 2 and Fig. 1, basil and castor oils showed no effect on Pseudomonas sp. and Aeromonas sp. While strong effect was recorded against $E$. coli and Vibrio sp. The maximum inhibition zones recorded of basil oil were at concentration $20 \mu \mathrm{l}$ for E. coli and Vibrio sp. respectively. In castor oil the maximum inhibition was in E. coli at conc. 20 and $40 \mu \mathrm{l}$ respectively. The minimum inhibition was recorded in Vibrio sp. and E. coli respectively at conc. $60 \mu \mathrm{l}$ with castor oil and at the same concentration in basil oil the inhibition was the lowest in E.coli. These results agrees with El Ashram et al., (2017) where there significant decreased in total bacterial count of fish muscle in compared with the control that may be due to the antimicrobial effect of basil oil. Suppakula et al., (2003) reported that basil essential oils exhibited good antimicrobial activity against a wide range of microorganism. In general, the clove and Peppermint oils recorded highly effect on all pathogenic bacteria. In many cases the maximum inhibition zone was recorded at low concentration (10 $\mu 1$.) On the other hand, castor and basil oils cannot effect on pseudomonas $s p$. or Aeromonas sp. These results provide evidence for the antimicrobial effects of the tested essential oils. This may be due to the presence of 
phenolic compounds. These compounds can degrade the cell wall protein, disrupt the cytoplasmic membrane and interfere with membrane-integrated enzymes (Shan et al., 2007).

\section{Conclusion}

It could be concluded that the clove and peppermint oils had the highest inhibitory action against $A$. wisconsinense. It's obtained also that both basil and castor oils showed an inhibition effect against alga growth at the three tested concentrations but less than clove and peppermint oils. Also the tested oils (Clove, Peppermint, Basil and Castor) had great antimicrobial effect against E. coli, Vibrio sp., Pseudemonas sp. and Aeromonas sp.. Clove and Peppermint oils effectiveness was observed against all examined bacterial pathogens while basil and castor oils had no effect against Pseudemonas sp. and Aeromonas sp. at any concentrations. Further studies are required to evaluate the different plants extracts against the tested microorganisms under laboratory and field conditions.

\section{REFRENCES}

Aoki, T. (1992). Chemotherapy and drug resistance in fish farms in Japan. In Sheriff M., Subasinghe R. and Arthur J. (eds.): Diseases in Asian Aquaculture, vol. 1. Fish Health Section. Asian Fisheries Society, Manila, Philippines, 519 - 529.

A.P.H.A.(1989). American Public Health Association, Standard methods for Examination of water and waste water, APHA, AWWA, WPCF, New York, 17th Ed.

Astani, A.; Reichling, J. and Schnitzler, P. (2010). Comparative study on the antiviral activity of selected monoterpenes derived from essential oils. Phytother. Res. 2010, 24, 673-679.

Bansemir, A., Blume, M., Schroder, S., Lindequist, U. (2005). Screening of cultivated seaweeds for antibacterial activity against fish pathogenic bacteria. Aquaculture, 252, 79-84, 2006. DOI: 10.1016/j.aquaculture. 2005.11.051

Bauer, A. W.; Kirby, W. M.; Sherris, J. C. and Turk, M. (1966). Antibiotic susceptibility by a standardized single disk method. Amer. J. Clin. Pathol. 45: 493-496.

Barani, M.; Yousefzadi, M.; Moezi, M.and Pejmanmehr, P.(2014). Effect of Higher Plant Essential Oils for the Control of Red Tide Algae Cochlodinium polykrikoides under Laboratory Conditions Journal of the Persian Gulf )Marine Science)/Vol. 5,No. 15,9:41-50. 
Burt, S. (2004). Essential oils: Their antibacterial properties and potential applications in foods-A review. Int. J. Food Microbiol. 2004, 94, 223 253.

Cañada, F. C., Muñoz de la Peña, A., Mansilla, A. E. (2009). Analysis of antibiotics in fish samples. Analytical and Bioanalytical Chemistry, 395:987-1008.

Chakraborty, S. B. and Hancz, C. (2011). Application of phytochemicals as immunostimulant, antipathogenic and antistress agents in finfish culture. Reviews in Aquaculture, 3: 103-119.

Chorus, I., Bartram, J., ed. (1999). Toxic cyanobacteria in water. A guide to their public health consequences, monitoring and management. Published by E \& FN Spon on behalf of the World Health Organization.

Direkbusarakom, S. (2004). Application of medicinal herbs to aquaculture in Asia. Walailak J Sci Tech, 1, 7-14, 2004.

Duncan, D. B. (1955). Multiple range and multiple F-tests. Biometrical, 11: $1-42$.

El-Ashram, A. M. M.; Afifi, A. A. M. and Sakr, S. F. (2017). Effect of basil oil (Ocimum basilicum) on nonspecific immune response of Nile-tilapia (Oreochromis niloticus).

Galina, J. G.; Yin, G. L.; Ardó, L. and Jeney, Z. (2009 ). Use of immunostimulating herbs in fish. An overview of research. Physiol. Biochem., Published online: 11 March 2009.

Hindi, N. K. K.; Chabuck, Z. A. G. (2013). Antimicrobial activity of different aqueous lemon extracts. J Appl Pharm Sci, 3, 74-78, 2013. DOI: 10.7324/JAPS. 2013.3611.

Kaloustian, J.; Chevalier, J.; Mikail, C.; Martino, M.; Abou, L. and Vergnes, M. F. (2008). Étude de six huiles essentielles Composition chimique et activité antibactérienne. Phytothérapie 2008, 6, 160-164.

Kim, D.; Oda, T.; Muramatsu, T., Kim, Daeil, Matsuyama, Y. and Henjo, T. (2002). Possible factors responsible for the toxicity of Cochlodinium polykrikoides, a red tide phytoplankton. Comparative Biochemistry and Physiology, 132: 415-423.

Kobaisy, M.; Mario, R.; Tellez, R.; Webber, C. L.; Dayan, F. E.; Schrader, K. K. and Wedge, D. E. (2001). Phytotoxic and fungitoxic activities of the essential oil of Kenaf (Hibiscus cannabinus L.) leaves and its composition. Journal of Agiculture and Food Chemistry, 49(8): 37683771 . 
Lam, A. K. Y., Prepas, E. E., Spink, D., and Hrudey, S. E.(1995). Chemical control of hepatotoxic phytoplankton blooms: Implications for human health. Water Research Volume 29, Issue 8, Pages 1845-1854.

Meeker, H. G. and Linke, H. A. (1988). The antibacterial action of eugenol, thyme oil, and related essential oils used in dentistry. Compendium 9(1) 32-35.

Najem, A. M., Abed, I. J. and AL-Haidari A. M. Dh. (2016). Evaluation the activity of Rosemary (Rosmarinus officinalis L.) essential oil against some Cyanobacteria. Iraqi Journal of Biotechnology Vol. 15, No. 1 , 97102.

Nikoli'c, M.; Jovanovi'c, K. K.; Markovi'c, T.; Markovi'c, D.; Gligorijevi'c, N.; Radulovi'c, S.; Sokovi'c, M. (2014). Chemical composition, antimicrobial, and cytotoxic properties of five Lamiaceae essential oils. Ind. Crops Prod. . r r r_r ro, TI

Paerl, H. W.; Fulton III, R. S.; Moisander, P. H. and Dyble, J. (2001). Harmful freshwater algal bloom, with an emphasis on cyanobacteria. The Scientific World Journal, 1: 76-113.

Pandey, A., and Singh, P. (2011). Antibacterial activity of Syzygium romaticum (clove) with metal ion effect against food borne pathogens. Asian Journal of Plant Science and Research, 1 (2):69-80

Reham, A. A.(2012). Antimicrobial production by some species of Cyanobacteria isolates from freshwater. Ph. D. Thesis. Botany Dept. Fac. of science. Benha Univ.

Rippka, R., Deruelles, J., Waterbury, J. B., Herdman, M., Stanier, R. Y. (1979). Generic assignments, strain histories and properties of pure cultures of Cyanobacteria. J. Gen. Microbiol., 111: 1-61.

Safaei-Ghomi, J. and Ahd, A. A. (2010). Antimicrobial and antifungal properties of the essential oil and methanol extracts of Eucalyptus largiflorens and Eucalyptus intertexta. Pharmacogn. Mag. 2010, 6, 172175.

SAS (2002). Statistical Analysis System, SAS User's Guide: Statistics. SAS Institute Inc. Editors, Cary, NC, USA.

Shan, B., Y.; Cai, J.; Brooks and Corke, H. (2007). The in vitro antibacterial activity of dietary spice and medicinal herb extracts. Int. J. Food Microbiol., 117: 112-119.

Sivonen, K. and Jones, J. (1999). Cyanobacterial toxins. In: Chorus I, Bartram J., ed. Toxic cyanobacteria in water. A guide to their public 
health consequences, monitoring and management. Published by E \& FN Spon on behalf of the World Health Organization, pp. 41-112.

Steel, R. G. D. and Torrie, J. A. (1980). Principles and procedures of statistics. 2nd ed., USA McGraw Hill pp. 183 - 193.

Stefanakis, M. K.; Touloupakis, E.; Anastasopoulos, E.; Ghanotakis, D.; Katerinopoulos, H. E. and Makridis, P. (2013). Antibacterial activity of essential oils from plants of the genus Origanum. Food Control 2013, 34, 539-546.

Suppakul, P. Miltz, J., Sonneveld, K., and Bigger, S. W. (2003). Antimicrobial properties of basil and its possible application in food packing. Journal of Agriculture and food chemistry. 51, 397 - 3207.

Venkataraman, G. S. (1969). The Cultivation of Algae. Indian Council of Agricultural Research, New Delhi, India.

Walsh, C. T. and Pease, B. C. (2002). The use of clove oil as anaesthetic for the longfinned eel, Anguilla reinhardtii (Steindachner). Aquaculture research 33, 627-635.

Wang, H.; Liang, F. and Zhang, L. (2015). Composition and Anticyanobacterial Activity of Essential Oils from Six Submerged Macrophytes. Pol. J. Environ. Study, 24 (1): 333-338.

Yi, Y. L.; Lei, Y.; Yin, Y. B.; Zhang, H. Y. and Wang, G. X., (2011). The antialgal activity of 40 medicinal plants against Microcystis aeruginosa. Applied Phycology, DOI. 10.1007/s10811-011-9703-2. 


\section{التأثير المثبط لبعض الزيوت الطبيعية الطيارة على طحلب البكتيريا الخضراء المزرقة (Anabaena wisconsinense)}

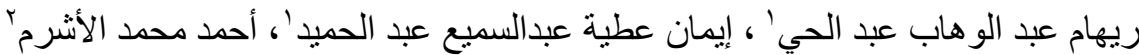

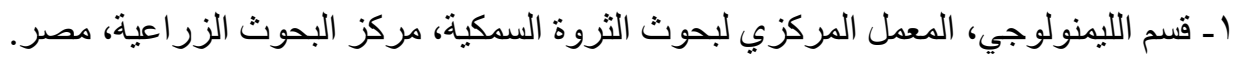

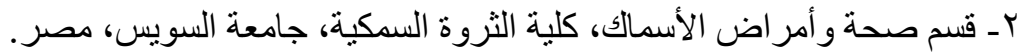

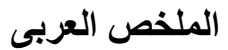

تهدف هذه الدراسة إلي إختبار التأثير المثبط لزيت القرنفل (Syzygium aromaticum) وزيت الريت

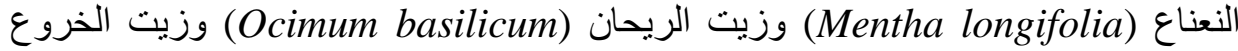
(Ricinus communis) Escherichia coli \& Vibrio sp\&) أربعة أنواع من البكتيريا المسبية للأمراض الزراه . Pseudemonas sp. Aeromonas sp

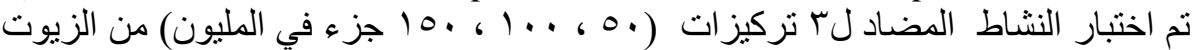

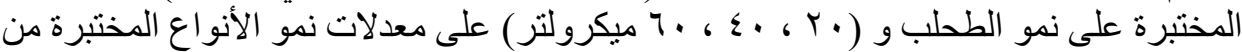

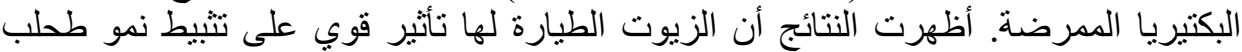
Anabaena wisconsinense A. wisconsinens

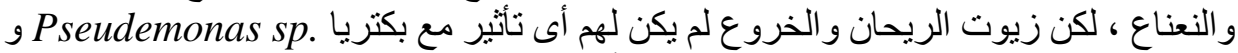
Aeromonas sp.

سجلت النتائج أن الطحلب والبكتيريا الممرضة أكثر حساسية للتأثثر المثبط لزيت القرنفل وزيت 